distant pinnacle. These peaks are frequently mistaken for Everest ; thus in the atlas accompanying the "Results of a Scientific Mission to India and High Asia " there is a large chromolithographed plate from a drawing by Hermann Schlagintweit of a mountain which he believed to be Everest; but the mountain is undoubtedly Makalu, as has recently been pointed out elsewhere. ${ }^{1}$ The best view of Everest from British territory is obtained at Sandakphu a well-known hill on the boundary between Nepal and Darjeeling ; but even there it is partly shut out from view by Makalu, which being exceedingly bold and picturesque in appearance generally comes in for more attention than its higher neighbour.

The pillars and posts marking the line of boundary between the Nepalese and the British territories, having in many instances been destroyed by wild animals or carried away by floods, survey operations have been undertaken, at the request of the Nepalese Government, with a view to relaying the line. This has afforded an opportunity of surveying the Sameswar Hills, the water-parting of which constitutes a portion of the boundary. A strip of the Nepalese territory which skirts the boundary has been sketched as far as circumstances would permit, and large errors in the topography of the tract, as laid down bitherto from native information, have been discovered and corrected. The Sameswar Hills are said to be very similar to the Siwalik Ranges, which the palæontological discoveries of Falconer, Cantley, and Baker have made so famous, excepting that the peaks are generally of less altitude, and the Pinus longifolia is almost entirely absent.

Major Holdich gives an account of the first ascent ever made by Europeans of the famous Takht-i-Suliman, or Throne of Solomon, the highest portion of the range of mountains on the western border of the valley of the Indus, which separates the highlands of South-Eastern Afghanistan from the plains of the Punjab. Viewed from these plains the Takht has the appearance of a ridge some 8 miles in length, much elevated above its surroundings, and with two culminating peaks at its northern and southern extremities,- apparently admirable points from whence to make a survey of the tract of country extenciing westwards almost as far as Candahar and Ghazni, of which very little is known. Lieutenant James Broadfoot, of the Bengal Engineers, travelled across it in 1839 , by the route from Ghazni to Deva Ismail Khan viâ the Ghwaleri Pass, of which he made a hurried sketch under great difficulties; and tine Zhob Valley to the south has been roughly mapped by a native explorer. But much more knowledge of the country was wanted, and this it was expected might be obtained by observations from the two great peaks of the Takht, the ascent of which had for many years been an object of laudable arnbition on the part of the Survey officers; they were greatly gratified when the Government authorised a survey expedition to be sent to the summit of the mountain, with a sufficient escort of troops to overcome any possible opposition. On reaching the summit the Takht was found to consist, not of a single ridge, but of two parallel ridges, with a plateau between, the highest point at the northern extremity ( 1,300 feet) being on the western ridge, while that on the southern extremity ( 11,070 feet) is on the eastern ridge, and is unfortunately shut out by the other from all view of Afghanistan. Thus the Takht was disappointing as a basis for distant geographical exploration; bit a good deal of valuable topography was secured of an important but little-known portion of the Sulimani Range, which constitutes the primary base for the defence of India from western aggression.

In Biluchistan Lieutenant the Honourable M. G. Talbot, R.E., and Lieutenant Wahab, R.E., made a valuable reconnaissance to the south-west of the little-known

"See "Notes on Mount Everest" in the Procedings of the Royal Geographical Society for February 1836. region which lies between Kelat, the capital, and the town of Gwadur, on the Persian Gulf; they worked over the Raskoh Ranges across the great plain of Kharan to the Lagar Koh and Koh-i-Sabz Ranges, and down to Panjgur. Much of the country traversed was a desert, and the scope of the operations had to be carefully adjusted to the limited available supplies of both food and water for men and animals.

The systematic tidal observations with self-registering tide-gauges, which were instituted under the superintendence of Major Baird, R.E., F.R.S., by the Government of India, in accordance with the recommendations of the British Association, have been continued at sixteen stations -including the ports of Aden, Kurrachee, Bombay, Madras, Calcutta and Rangoon, and Port Blair-completed at two stations, Kárwár and Pámban, and commenced at three new stations, of which two are on the Island of Ceylon, more under the direct influence of the Indian Ocean than the stations on the coasts of India. Good progress has been made with the lines of spirit-levels which are carried between the tidal stations, both along the coast lines and across the peninsula from coast to coast. So far as yet completed the operations indicate that the mean sea-level may be regarded as practically identical at all points on the open coast.

The Calcutta International Exhibition has necessitated a considerable extension of the operations of the lithographic and photographic offices under Colonel Waterhouse; the processes of heliogravure and collotype were found very serviceable in reproducing the delicate objects of Indian art-work which were exhibited. In the first of these processes a valuable improvement has been effected; originally the engraved copper plate was obtained by developing a positive pigment print, or relief in hardened gelatine, on a silvered copper plate, and then depositing copper upon it so as to form a new copper plate, bearing the design in intaglio, from which prints can be taken in the usual way. In the new process a negative pigment print is developed on a copper plate, and the intaglio image is obtained directly on the plate by biting in with a chemical solution, which penetrates the gelatine film comparatively easily in those parts representing the shadows of a picture or lines of a map, where there is little or no gelatine, biting the copper to a considerable depth; whereas in the parts representing the light of the picture or the ground of the map, where the gelatine is thicker, it penetrates with more and more difficulty as the tbickness of the gelatine increases, and in the highest lights should leave the copper untouched. The operation of biting does not take more than five minutes, and the engraved images are said to be marvellous in their delicacy of gradation and richness of effect. The great advantage of the process is its rapidity, a day or two being sufficient to prepare the etched plate, whereas from three weeks to a month are required to "deposit "a printing plate of sufficient thickness by photo-electrotyping ; on the other hand, it is difficult to get etching of sufficient depth to stand much printing without the loss of the finest tints.

The Report contains many other items of interest which our limits do not allow us to notice. It has evidently been compiled with much care, though there are occasional slips, as at page 3, where the country of Kafiristan is referred to as " an explorer in the service of the Educational Department," and the scale of the survey of that country is said to be "confidential." I. T. W.

\section{SCIENCE SCHOOLS AT HOME AND ABROAD}

$\mathrm{N}$ this volume Mr. Robins has collected together a series of communications which have appeared at various times in the Fournal of the Society of Arts and

I "Papers on Technical Education, Applied Science Buildings, Fittings, and Sanitation." By. Edward Cookwortny Robins. (London, I886.) 
in the Transactions of the Royal Institute of British Architects. The republication of these papers coming so soon after the last Report of the Commission on Technical Education is most opportune. We have here, brought as it were to a focus, a mass of detail relative to the planning, construction, and mode of equipment of the most noteworthy schools of science of Europe. To the teacher of applied science, and especially also to the many bodies of public-spirited men who are engaged both in London and in our midland and northern towns in the erection of buildings for applied science and art instruction, the work must be in the highest degree valuable. The mere collection of the facts themselves could not fail to prove of the greatest service to the cause of technical education in this country; but when the facts are, as it happens, arranged, co-ordinated, and criticised by one who has himself had no inconsiderable experience in designing buildings of this class, the collection becomes simply indispensable.

In the first paper, on "English and Foreign Technical Education," Mr. Robins seeks as it were to clear the ground. In this matter, as in so many others, it is the houses which obscure the view of the village. Mr. Robins therefore attempts to state precisely what it is that technical education aims at, and how we may reasonably hope that the aim may be attained. It is of course only after the lines have been laid down upon which the teaching of technology should proceed that the question of appliances and buildings can be properly approached. It is necessary therefore to carefully analyse the results which have been obtained abroad, for we have at present little to appeal to at home, and even that little has been too recently in operation to afford a basis for sound conclusions. We have as yet no system. That is, of course, characteristic of us, for we are continually reminded that we are, in some respects, the most illogical people in the world. Nothing in our whole educational history is more characteristic of us-of our energy, public spirit, and independence-than the way in which with much effort, laborious and occasionally ill-directed, and with no inconsiderable expenditure of money, we are hammering away at this question of teaching technology. In Yorksbire alone there is at the present moment probably every type of technical school more or less imperfectly developed, which the ingenuity or perversity of man could devise,-from the school which does nothing but handicraft pure and simple, up to that which concerns itself mainly with the science of practice, and relegates practice itself to the workshop. The men who are struggling with this problem of grafting a high-class scientific education upon the daily work of our towns are the manufacturers, the engineers, and merchants of our great commercial centres. These men - - the men who build the big bridges, bore the big tunnels, sink the deepest mines, set up the highest blast-furnaces, and gauge their power for civilisation, as Liebig said, by the size of their vitriol chambers-have a silent horror and tolerant contempt for doctrinaires. Mr. Froude may say of the age of patriotism-as Burke said of the age of chivalry-that it is dead. But England owes a debt of gratitude to those who are thus struggling to keep her in the forefront of the battle for industrial supremacy among the great producing peoples of the world, and who are unstintingly spending time, energy, and money in the determination that their sons and the generations to come shall reap some of the benefits of knowledge that were denied to them.

In Mr. Robins's first paper, published in I 882, there is much relative to the Continental systems which has been supplemented by the Report of the Commission, but regarding it simply as introductory to the purely professional papers which constitute the most valuable feature of the book, it would be necessary to modify it in but few and comparatively unessential details.

In the next paper, on "Buildings for Applied Science and Art Instruction," Mr. Robins gives a detailed account, mainly compiled from personal visits, of the most distinctly representative buildings of this class to be met with in Germany, Austria, Sweden, and in our own country. In this paper we have the first attempt to formulate the general principles which should govern the planning of buildings intended for technical instruction. All technical education does not need special accommodation. Mr. Robins points out that the ordinary class-rooms attached to school buildings may be appropriated to certain kinds of technical instruction provided that they are properly lighted and ventilated. But there are many subjects which can only be efficiently taught in specially-designed buildings, as, for example, chemistry and physics, mechanics and engineering, architecture, \&c.,-in fact, all involving the provision of laboratories, lecture-theatres, work-rooms, modelling-rooms, \&c., which have to be grouped in a certain order and contiguity, and which must be specially floored, lighted, heated, and ventilated, and arranged for particular furniture and fittings or special apparatus. It is with buildings of this class that we are at present more particularly concerned.

In Germany, and in the German-speaking part of Europe generally, the system of working the different subjects in separate buildings is now almost universally regarded as the most convenient arrangement. Thus at Berlin, Prof. Helmholtz's physical laboratory and its associated classrooms and lecture-rooms are in one grand building, and Prof. Du Bois-Reymond's physiological laboratory is in an adjoining building-worthy companions of the handsome structure erected for Prof. Hofmann so long ago as I 865 . At Leipzig is a street full of separate and distinct buildings for these subjects, supplementing the old University provisions. At Geneva, Prof. Graebe has designed and superintended the general arrangement and fittings of the new chemical laboratory, also situated apart from the University proper. Profs. von Pebal and Toepler at Gratz, Prof. Landolt at Aachen and Berlin, Prof. Baeyer at Munich, have each worked out, with the respective architects, the details of their new and remarkably wellfitted laboratories. At Strasburg the new University buildings are also constructed in separate blocks. In addition to the main building for classical studies and general literature, distinct blocks are arranged for physics, chemistry, botany and forestry, mineralogy, \&c., each block costing from $30,000 l$. to $40,000 l$, , built in the classic style, faced with stone from the Harz Mountains, and together covering several acres of ground.

In addition to these Mr. Robins adds, as types of less ambitious places, an account of the chemical and physical laboratories of the Royal Trade School at Chemnitz, of Prof. Kohlrausch's physical laboratory at Wurzburg, of the Technical High School at Hanover, of the Royal Technical High School at Stockholm, and of the Chalmers Industrial and Technological School at Gottenborg.

It would be quite impossible, with the space at our disposal, to attempt to follow Mr. Robins in his analysis of the distinctive features of these various institutions. He has treated the mass of material thus brought together in a remarkably clear and lucid manner. There is necessarily much in every chemical laboratory which is common to all, and the same remark applies to every other laboratory or workshop in which technology is taught. Nothing more certainly indicates the trained professional eye than the manner in which characteristic differences are detected and commented upon, and it is the evidence of this diagnostic faculty which constitutes one of the most valuable features of the book.

But perhaps the most generally interesting portion of Mr. Robins's work is that relating to the applied science buildings which have been erected in this country. These consist of the Central Technical Institution at South Kensington and the Technical College at Finsbury, both erected by the City and Guilds of London; the Owens 
College, Manchester; the Yorkshire College, Leeds; University College, London; the Mason College, Birmingham; and the Merchant Venturers' School at Bristol. As a typical school laboratory Mr. Robins has very judiciously chosen that of the Manchester Grammar School. We have selected for reproduction here, from among the many sheets of plans with which Mr. Robins's papers are illustrated, portions of the plans of the Central Institute, the Yorkshire College (Leeds), and the laboratories of the Merchant Venturers' School at Bristol, as types of institutions engaged in the work of teaching how science is to be brought to bear upon the industries of this country. In the Merchant Venturers' School we have a building specially constructed for teaching science to large classes of boys; in the Yorkshire College the arrangements, as regards science, were designed with reference to the requirements of students receiving specialised teaching, and who intend to pass into manufactories or workshops, or to become professional chemists, physicists, or engineers ; in the Central Institute we have the most highly developed type, designed for selected students coming from the Finsbury College or from the provincial colleges, and who already have a basis of sound scientific knowledge, and are thereby fitted to receive special and advanced instruction in various branches of technology. A careful comparison of the plans of Mr. Waterhouse's buildings, viz. the Yorkshire College and the Central Institute, with that of Mr. Robins erected for the Merchant Venturers, will serve to show how the particular requirements of each class have been met in the case of chemistry. It will be seen that the number and relative size of the various rooms, their mutual position, and internal arrangement of worktables, \&c., are very different in the several buildings, and that these differences are primarily dependent upon the special type of instruction which is contemplated.

In the next paper Mr. Robins deals with the fittings for applied science instruction buildings. Strictly speaking, the two questions of fittings and structure cannot be considered apart, for, as Mr. Robins very truly remarks, "it is of the utmost importance in a truly economic aspect of the question that the architect should possess from the very outset a clear preconception of the structural provisions involved in the particular system of fittings intended." The paper has especial reference to the fittings of chemical and mechanical laboratories; it is singularly full and complete, and admirably illustrated. The fittings of every laboratory of note have been well studied, and the facts are so detailed that the merits of any particular arrangement can be readily determined. It is certain to be of the greatest service to any architect engaged in the erection of this special kind of building.

The last paper which we have space to notice deals with the important question of the heating and ventilation necessary for applied science instruction buildings. It is principally based upon details of the means adopted in four of the most modern erections in this country, viz. the Finsbury Technical College, the Central Institute (South Kensington), the Yorkshire College, and the Merchant Venturers' School. These buildings are characterised by very wide differences in compactness and in the relative proportions of inside and outside walls ; and the particular modes of heating, that is, whether by steam or hot water, are also different. In some of the buildings the vitiated air is extracted by a chimney, or by a fan ; in others the fresh air is forced into the buildings by a fan. Each system has its merits and defects, and most of these are pointed out in the paper, or in the appendix containing the remarks made during the discussion which followed the reading of Mr. Robins's paper at the Institute of British Architects.

It will be seen therefore that $\mathrm{Mr}$. Robins has treated this question of the provision of buildings for applied science instruction in a remarkably comprehensive manner. The collection of papers is certain to be of the greatest service to any architects engaged in the erection of buildings of this class; it constitutes, indeed, a sort of vade mecum to the building committees who may be responsible for the selection of the architect's plans. The cause of technical education in this country is under a debt of gratitude to $\mathrm{Mr}$. Robins for the service which he has thus rendered to it.

T. E. IHORPE

\section{FULES FAMIN}

A SHORT time ago we announced the death of the A eminent French physicist, Prof. Jamin.

By the courtesy of the editor of La Nature we are enabled this week to give an excellent portrait, to which we add a brief sketch of his scientific career, for the details of which we are indebted to the same source.

Jamin was born, in 1818 , in the village of Termes in the Ardennes. He was the son of Anthony Peter Jamin,

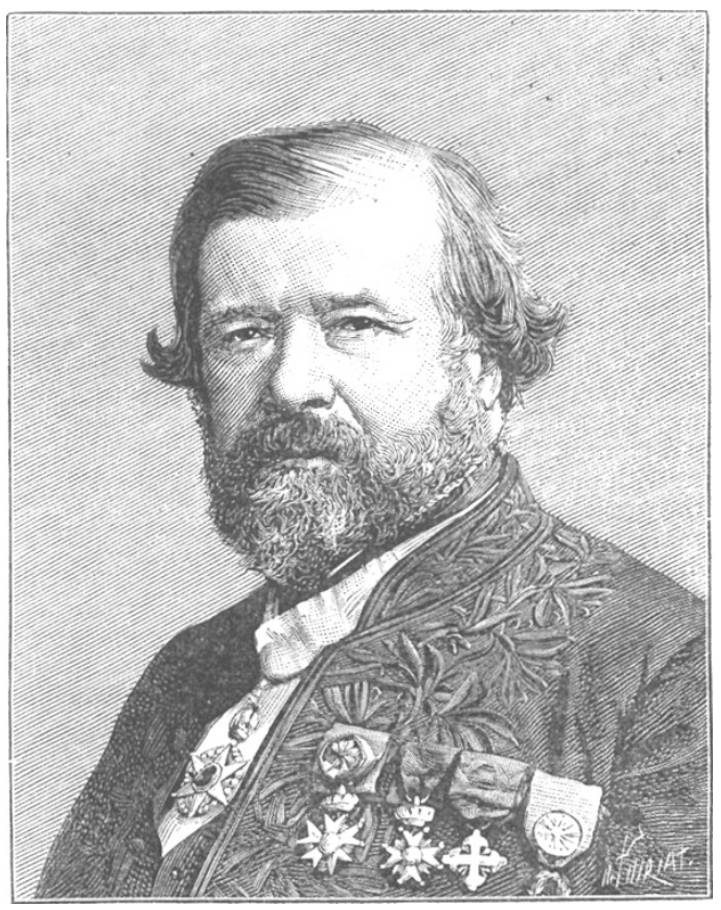

who engaged as a volunteer in 1795, was appointed Captain and decorated at the battle of Friedland, and afterwards retired to his native country. Jamin was brought up first in a little school in the village of Vouziers, and his father sent him to the College at Reims.

At the end of the first year there Jamin had gained nine prizes, and in 1838 his work was crowned with the prize of honour in a general competition between the Colleges of Paris and the Departments. In the same year he entered the École Normale Supérieure, and three years after, in $184 \mathrm{I}$, he came out first prizeman in physical science. He was then appointed to the College at Caen, where he succeeded Desains, whom he found later as colleague at the Sorbonne, and survived only a few months. At the end of two years he was called to Paris as Professor of Physics at the Collège Bourbon. The following year, in 1844 , he became Professor at the College of Louis-le-Grand, where he continued his researches commenced at Caen, and he received in 1847 his Doctorate of Physical Science for a thesis, now a classic, on the reflection of light on the surface of metals.

The precision, elegance, and solidity of his instruction, 